دراسات في آثار الوطن العربي 16

\title{
Scenes portray the daughter in the ancient Egyptian civilization and its Connotations
}

\section{Manal Ismaiel Tawfik ${ }^{*}$}

The ancient Egyptian called his daughter several names, including "Sat", meaning daughter, "Sherritt" meaning little girl or daughter, and "ktt" also means a child . $\left(^{1}\right)$

Egyptian family characterized by acceptable balance between the couple and a convergence reasonable in a transaction his sons, Boys and girls, Which is purer spirit of forgiveness out was not the teachings of the wise and the meanings of the names of birth is only the mouthpiece of the models of this convergence and balance, But the arts expressed about it too, The ancient Egyptian art whole different branches of engraving carving, and Portrayed have a many archaeological evidence which came to portray the daughter of topics and a variety of areas and in different situations.

In addition to persons portrays of the men and women separately, The art took us a lot of fine art pieces and scenes for interconnected Egyptian family groups, Include husband and wife, Sons and daughters.

Traditionally when a father portrayed with his sons and daughters writing that they are all sons and loved him, and that wrote with all of them his name, Which is witnessing a relative fairness between the sexes, And the community accept to draw appropriate female activities along with the man's activities are equally the Royal daughter with public.$\left(^{2}\right)$

\footnotetext{
* Assistant professor for Ancient Egyptian Archaeology agent Cairo Higher Institute for Tourism and Hotels.

1 - Gardiner, A. , Egyptian Grammar, London, Oxford University press, 1973, p, 610;

Abd el Halim Nur al-Din, The Role of ancient Egyptian women in society, Supreme Council of Antiquities, Cairo, 1995, p. 164.

2 - Abd ul Aziz Saleh, The Egyptian family in the old ages, Cairo,.1989, p. 100 -110.
} 
Through the review of many of these Archaeological and included evidence of portrayed the daughter we can demonstrate and deduce status of the daughter in ancient Egyptian society at various levels as follows:

\section{The Art}

The daughter portrayed in various technical products in varying ages and conditions :

\section{The Sculpture}

- In the field of sculpture the daughter depicted in a variety of situations, including the individual, such as statues of Princess Mert Amon daughter of King Ramses II, including her Statue of limestone, Portrayed standing wearing a feathers crown, It found in Akhmim at Sohag ( Figure 1), and another Statue of limestone of Ramesseum Temple, Portrayed standing with smooth features, It is in Egyptian Museum ( figure 2) $\left(^{3}\right)$, And a statue of alabaster for The Divine worshipper Amon Redis, Daughter of King Kashta of the Late Period, Of a temple of God Monthu at Karnak in Egyptian Museum (Figure 3) $\left(^{4}\right)$, A wood statue for a little girl of the Twenty first Dynasty of Saqqara, portrayed naked put her finger in her mouth and put a long earring in her ears( Figure 4).

- In the bilateral statues such as a limestone statue for the king Ramses II and his daughter of the Karnak Temple, Where we see she is standing in front of the legs of her father's in small size is up to the beginning of the kilt, Where she put the crown on her head and the right hand is unfolded, Either the left held on her chest stuck a flower (Figure 5), The limestone statue of King Akhenaten kissing his daughter as we see her sitting on his legs, She put her feet on the base and the artist has portrayed both of them at profile, Was found in Tel El-Amarna, It is in Egyptian Museum (Figure 6) $\left(^{5}\right.$ ), Another statue of colored limestone for

3 - F. Tiradritti, The Treasures of the Egyptian Museum, American Universty in Cairo press, Photographs by A . De Luca, Cairo, p.261.

4 - F. Tiradritti, The Treasures of the Egyptian Museum , p. 278.

5 - F. Tiradritti, The Treasures of the Egyptian Museum, p.186. 
دراسات في آثار الوطن العربي قال

a woman of public combing her daughter hair, They sitting on a rectangular base, Where we see the mother extends her legs while her daughter sitting on them in Egyptian Museum (Figure 7). $\left({ }^{6}\right)$

- In many of statuary Group "family statues", including the big seated statue of limestone for the King Amenhotep III and his wife Queen Ti, portrayed his daughter beside the leg of her father, She is stands in a small size, It is in Egyptian Museum (Figure 8) ${ }^{7}$ ), And a seated statue of gray granite for the mayor of Thebes in the Reign of King Amenhotep II, Snfer and his wife Snnay, Where we see in the mid statue next to the legs of her parents stand their daughter's Mout Nfert, Which depicted again by inscription was sitting in front of an offering table on the right side of the couch, Which sits by her parents, While her sister Nefertari portrayed in a similar scene on the left side of the same couch, The statue of the Temple of Amun at Karnak and in Egyptian Museum (Figure 9) $\left(^{8}\right)$, Colorful limestone Statue for Mrso Ankh the high funerary priest group of the Fifth Dynasty, Mediates his daughters, The great "Ie Merritt" and the minor "Hathor Wr", of his tomb at Giza and it is in Egyptian Museum, The statue holds a features family-friendliness (Figure 10) $\left({ }^{9}\right)$, Another colored limestone group statue for dwarf "Snp" and his family of the Fifth Dynasty, Where we see his daughter actress as a naked girl on the front of the seat, Bottom of the held legs of her father, Of his tomb at Giza and in Egyptian Museum a statue holds also features family-friendliness ( Figure 11) $\left({ }^{10}\right)$, Another colored limestone group statue of Nfer Hern Petah "Fifi" the Psalmist priest and the supervisor of the funerary rites of King Khafre and Man Cao Ra, Where we see his daughter "Merritt It

6 - T. Handousa , Marriage and divorce in ancient Egypt, Cairo, 1998, Pl. 1.b.

7 - Abd el Halim Nur al-Din, The Role of ancient Egyptian women in society, p.29.

8 - F. Tiradritti, The Treasures of the Egyptian Museum , p.344.

9 - M. Saleh, \& Horig Suruzaan, Catalog of Egyptian Museum, The Supreme Council of Antiquities ,1999, p. 54.

10 - F. Tiradritti, The Treasures of the Egyptian Museum , pp. 74-75. 
S" portrayed sitting on a chair without back to the left of her standing father as equal size of her brother who sitting on the other side of the same statue, Of his tomb at Giza, It is in Egyptian Museum (Figure 12) $\left({ }^{11}\right)$, Another gray granite group statue of "Okh Hotep" and his family, He was a provincial governors in the age of Twelfth Dynasty, It includes two wives and one of his daughters, Which portrayed standing left her father and next to her mother in the same form body but in small size, Of his tomb in Mair, It is in Egyptian Museum (Figure13) $\left({ }^{12}\right)$, There is also a colored limestone statue group of "Wny" and his wife of the New Kingdom, portrays sitting and synaptic hands, While their daughter portrayed by engraving gummy without prominence, She standing in the middle between the legs of her parents which provide both of her hands at the touch of tenderness for each of them, It is in Egyptian Museum (Figure 14) $\left({ }^{13}\right)$.

The Ancient Egyptian keenness on representation of his sons and daughters on the false door in his tomb to ensure them company in the other world, As he want ensure the offerings for them, For examples the wood false door of " Ika ", The royal priest cleanser and governor of the Great House in fifth Dynasty, his daughter portrayed by Gummy inscription and small size in front of her mother on the right side of the door while he portrays with his son on the opposite side, the door in Egyptian Museum (Figure 15). $\left({ }^{14}\right.$ )

\section{The inscription}

Ancient Egyptian architecture give us many scenes carved on the walls of tombs, and many different temples, which portrayed the daughter in several scenes of a variety of topics:

11 - F. Tiradritti, The Treasures of the Egyptian Museum , pp. 86-87.

12 - M. Saleh, \& Horig Suruzaan, Catalog of Egyptian Museum , p. 68.

13 - E. Suys, La Sagesse d' Ani " Roma Pontificio istituto biblico", 1935, XXII, 126, Analecta Orientalia No,II,III, 13-17.

14 - M. Saleh, \& Horig Suruzaan, Catalog of Egyptian Museum, p.57; F. Tiradritti, The Treasures of the Egyptian Museum , p. 84. 
The tomb of Queen "Mr-S-Ankh" daughter of "Ka-Oeb" and granddaughter of "Khufu" of Fourth Dynasty, Including afford walls of scenes and sculptures a good example for daughter portrayed, It is a rocky tomb is located east of the Great Pyramid of Giza, Tomb,s walls bearing many of the scenes and wall statues of the Queen Mr-S-Ankh with her mother Queen "Hotep Hres", The wife of King Khufu (Figure 16) $\left({ }^{15}\right)$.

Many scenes of Queen "Hatshepsut" were portrayed on the walls of her temple in Dair El Bahari as a divine birth in the second balcony, including the scene of Amun offers Hatshepsut to "Ahmose Nefertari", the mother of Queen Hatshepsut (Figure 17), and another scene came on his Obelisk in the Karnak Temple, Where we see her sitting in front of god "Amun" who sits on his throne as his daughter, extends his hands to give her protection and blessing (Figure 18) $\left({ }^{16}\right)$.

The scenes of King " Akhenaten" with his family of Tall El Amarna, In two different scenes on panels, Which appear with his daughters in different themes, In the first scene we see "Akhenaten" and Queen "Nefertiti" sitting and carrying them daughters actresses at a young age, Above all them the sun with human hands icon of Aten, and the scene shows friendliness and extreme love to their daughters (Figure 19), Second scene portrays each of Akhenaten and his wife as standing and behind them two of their daughters making offerings to the God Aten (Figure 20$)\left({ }^{17}\right)$, Another scene of daughters of King Ramses II during Jubilee celebration "heb sed". $\left({ }^{18}\right)$

15 - D.Dunham \& W.K. Simpson, The Mastaba of Queen Mersyankh III, G 7530- 7540, Boston, 1974; Manal Ismail TawfiK, Funerary Architecture in Pharaonic Egypt, Old and Middle Kingdoms, Cairo, 2014, p. 202.

16 - Pascal Vernos, Jean Aoiyot, Encyclopedia of the Pharaohs - names - places - topics, translation Maher Mahmoud Taha, Cairo 0.2001, p. 125.

17 - G.Aldred, Akhenaten, King of Egypt, London, 1986, 213; F. Tiradritti, The Treasures of the Egyptian Museum, p189.

18 - Christian Dirosh Noblchor, Pharaonic women, translation Fatma Abd Allah Mahmoud, Cairo, 1995, p. 163. 
As for the individuals scenes including : Scene of "Sherry" tomb the high royalists funerary priest group of the Fifth Dynasty of Saqqara, Portrays his wife "Eint" and his daughter $\left({ }^{19}\right)$, And another scene of "Mery- Aa" tomb of Sixth Dynasty portrays the first and favorite wife which did not give birth to him, She receives gifts of his children of other five wives in tow scenes, we see her standing next to her husband to receives gifts of his sons in the top register while sitting to receives flowers of his daughters in the bottom register, and the artist explained proportions each of them to his mother (Figure 21) $\left({ }^{20}\right)$, Many scenes of Okh-Hotep tomb the last provincial governors of Twelfth Dynasty in Mair, Including portrays scene on a fishing trip with his only daughter, Which sits in the middle of the boat, Where she appear between her father legs holding a bird like maintains the poise of the boat (Figure 22) $\left({ }^{21}\right)$, Another scene of "Dedu Sobek" tomb of Abydos of Middle Kingdom, Portrays him on a colored limestone stela with a round top, Where we see the tomb owner sitting in front of an offering table while his daughter sitting on his feet embraces her affectionately (Figure 23). $\left({ }^{22}\right)$

As for the scenes of the New Kingdom, We find many scenes in tombs of Deir El-Medina group in western Thebes, including: scene in the tomb of the painter "In Hri Khao", Portrays the owner and his wife with his granddaughters receiving offerings, Therefore show a scene of four girls in the different ages and conditions, Three of them were standing and the fourth is sitting (Figure 24) $\left({ }^{23}\right)$, Another scene for "Nb $\mathrm{N}$ Maat" in Deir ElMedina of the New Kingdom, Which we see $\mathrm{Nb} \mathrm{N}$ Maat plays

19 - Porter and Moss, Topographical Bibliography of Ancient Egyptian Hieroglyphic Texts, Reliefs and Paintings, Oxford, 1931, vol.III, p. 101 ; Mariette, Les Mastabas de L'Ancien Empire, Paris, 1889, pp.93-94.

20 - F.Petrie, Athribis , Egyptian Research Account, t.XIV, London, 1908, pL.VII.

21 - Blackman, Meir VI, "The Tomb of Ukh-hotp", London, 53, CNo 1 p.9 ff, pl.XVI, p.21.

22 - F. Tiradritti, The Treasures of the Egyptian Museum, p.96.

23 - T. Handousa, Marriage and divorce in ancient Egypt, P1. 1.a. 
the ancient Egyptian Cenet game with his wife while his daughter standing behind her father to watching the play, She portrayed in the same mother form but in a small size (Figure 25) $\left({ }^{24}\right)$, Another scene of Nfr Rnept tomb,s "kenzo" of Al khokha in Luxor, Portrays the owner of the tomb playing the Cenet game also, But with his daughter while his wife sits beside him to watching and share (Figure 26) $\left({ }^{25}\right)$, Another scene of Nkht,s tomb portrays him fishing with his family, His wife standing behind him and his daughter sitting clutching his leg in one of her hands while stuck flowers with the other hand (Figure 27), And another scene of the Sen Nedjem,s tomb of Deir El-Medina Reign of King Ramesses II, We are seeing him sitting with his wife, They receive offerings of a priest, His daughter portrayed on the bottom of the wife legs in a small size (Figure 28), Another scene on Papyrus in British Museum of London, Portrays a wife and his daughter deposited the deceased husband and father in grief, Daughter portrayed on her knees sobbing in front of her father Which actor in a mummy (Figure 29) $\left(^{26}\right)$, Another scene of the "Ra Moza" tomb the minister of King Amenhotep III of Thebes, Which portrays some young girls with a group of mourners may be them daughters, Working in the same craft on the grounds that the character mostly was genetic, or they daughters of the deceased's family (Figure 30) $\left({ }^{27}\right)$, Another scene of "Nfr Hotep" tomb of Thebes, Portrays a ceremony supervisor expelled one of musician, Holding negligently the musical instruments in the left hand while the vessel flying in front mouth with the right hand, And accompanying her two of her children, boy and girl, The girl

24 - W. Decket, Sports and Games of Ancient Egypt, Tr.A., Guttmann, The American University in Cairo Press, 193, p.130.

25 - T. Handousa , Marriage and divorce in ancient Egypt, Pl.3. a-b.

26 - Abd el Halim Nur al-Din, The Role of ancient Egyptian women in society, p.99.

27 - Christian Dirosh Noblchor, Pharaonic women, p.153; Abd el Halim Nur al-Din, The Role of ancient Egyptian women in society, p.96-98. 
دراسات في آثار الوطن العربي

carrying a bunch of grapes in her hand (Figure 31) $\left({ }^{28}\right)$, Another scene of "Raaia" tomb of Nineteenth Dynasty of Saqqara portrays him and his wife "Mout M Oya" sitting in front of an Offering table, While his daughter sitting on the cushion and holding a bird in her hand bottom of the wife chair, may be the dead desire to be with him in the other world (Figure 32) $\left({ }^{29}\right)$.

\section{The Authority}

Specialize out the royal daughter because the daughter authority of a public have not been portrayed through archaeological evidence, But we can deducted it through texts, And the authority includes tow meaning, The political and religious meaning, The royal daughter has won a great deal of authority in some periods of Ancient Egyptian history not as a wife king but as a independent governor Queen, which did not be usual or acceptable for ancient Egyptians, That in a suitable conditions at the ends of Dynasties, So they made some of the events of history and formed a part of civilization, There are many Queens who sit on the throne of the country since the beginning of history even the ends of the New Kingdom, Their number has reached about six Queens making Egyptian civilization superior to other contemporary civilizations and give it a leading position .

\section{Of these Queens:}

- Queen "Mert- Neit" of the first Dynasty, Some people questioned at that and considered her a wife of the King Den only, Not as a independent Queen, but we are found for her two tombs, The first one northerly in Saqqara and the other southern in Abydos $\left({ }^{30}\right)$, and her name mentioned Accompanying by the

28 - N. de G. Davies, The Tomb of Nefer- Hotep at Thebes, vol. I, New York, 1933, pls.V, XIV, XV, XVIII ; W. Wreszinski, Atlas I , Taf. 170 ; E. Feucht, Das Kind im alten Ägypten, Frankfurt/ New York, 1995, p. 359.

29 - G.T.Martin, The Hidden Tombs of Memphis, London, 1992, p.130, fig. 88; id., The Tomb - Chapels of Paser and Raa ia at Saqqara, London, 1985, p.14, pl.24.

30 - Ahmed Fakhry, Pharaonic Egypt, Cairo.1981, p. 81. 
title of Queen on a panel, Petrie found it in her tomb of Abydos (Figure 33) . $\left({ }^{31}\right)$

- Queen "Khnte- kaws" of the fourth Dynasty, She taken the royal titles as a Queen of Upper and Lower Egypt, Which are visible evidence on independent ruled, Some people questioned in her independent ruled also and consider her daughter of king "Mn- Kao Ra" only, and she is the legitimate heir to the throne, She was the reason for the transfer of authority for the Fifth Dynasty with her marriage by Userkaf (Figure 34). $\left({ }^{32}\right.$ )

- Queen "Neit- Ackrt" "Nitocris" of Sixth Dynasty, which revolved around her many myths, But the most important story is her suicide after revenge From who killed her brother, Manathon said she was one of the most beautiful women, Her name reported in the Turin Papyrus and history of Manathon as a Queen. $\left({ }^{33}\right)$

- Queen "Sobek- Nfro" of Twelfth Dynasty in Middle Kingdom, Likely she is the daughter of King "Amenemhat III", But she took the authority after "Amenemhat IV", Her name reported in the list of Saqqara, The Turin Papyrus and history of "Manathon", And carried the royal titles, including Queen of Upper and Lower Egypt, belonging to the goddesses Lady of Two Lands, her statue in Metropolitan Museum ( Figure 35). $\left({ }^{34}\right.$ )

- Queen "Hatshepsut" The most important Queen of Eighteen Dynasty, stronger than the rule of women, And most influential of them, She is the daughter of King Thutmose I and Queen "Auah-Moss", And the legitimacy heiress, Took the authority after her father, She married her brother Tuthmosis II and bearing the king's daughter and King,s sister title, and wife of the

31 - Abd el Halim Nur ed din, The history and Civilization of ancient Egypt, vol.1, Cairo, 2009 , p. 161.

32 - R.el Sayed, The history of ancient Egypt, vol. 1, since ancient times until the end of the Second Intermediate Period, the Supreme Council of Antiquities, Cairo, 1988, p. 215.

33 - R.el Sayed, Quelques homes céèbres:Egyptian Society for Historical Studies Journal, Issue 26.1979, p. 23.

34 - W.Petrie, Kahun, Gurob and Hawara, London, 1890, pl.26 (12); A.Weigall, Histoire de 1,Egypte Ancienne, Paris, 1949, p.82. 
God, Hatshepsut hadn't been born a boy, But gave birth to a girl called Neferu Re, While begotten Tuthmosis II was born of a secondary wife Isis and he called Tuthmosis III, So after Tuthmosis II death, Hatshepsut married him of her daughter and declarer her self as executor of the throne, But after a few years Hatshepsut excludes Tuthmosis III and declared her self as a Pharaoh, And bearing full royal titles and wearing the men uniform ( Figure 36) And recorded a divine birth on the walls of her temple in Dier El Bahari to pigmentation her verdict full legitimacy. $\left({ }^{35}\right)$

- Queen "Ta- Usert" of Nineteenth Dynasty, Some may disagree about being the wife of the king Merneptah or Siti II, But surely being independent ruled, Evidence found on the basis of deposits bearing her name in one of the funerary temples in Luxor, Including a block of carved stone by two Kartosh, The first unprecedented title King of Upper and Lower Egypt includes the name of "Sat Ra Merit Amun", and the second begins title "Sa $\mathrm{Ra}$ " and includes the name of "Tausirte Sitbt N Mout", There is also a piece of stone in the Egyptian Museum bearing a text begins with "the eighth year of the reign of Queen Tausirte" ( Figure 37). $\left(^{36}\right.$ )

As for the religious authority has manifested in the greatest forms at the ends of the New Kingdom, And during the Late Period, Where shows post is most important positions of the Egyptian priesthood, It is "campus Amon sacred" or what is known as the "divine worshipper " or " divine women in Thebes", Which means who refuge to gad and gaining of his sanctity and oversees on the sanctities and his priestess, Which was limited to Royal daughter have singled him some Queens and celebrities princesses, It has begun as a ceremonial post then

35 - UrK IV, pp. 59,60, 216-234; Weigall, Histoire de 1,Egypte Ancienne, p.109; SuzanneRatie, la Reine-pharaon, Paris, 1972, pp.22-24.

36 - W.Petrie, Kahun, Gurob and Hawara, London, 1890, pl.26 (12); A.Weigall, Histoire de 1,Egypte Ancienne, Paris, 1949, p.82; Abd el Halim Nur al-Din, The Role of ancient Egyptian women in society, pp.18-24. 
combine religious nature administrative top and influence in the temple of Karnak and Thebes city, That post gives his owner the authority and money together, Because there are many property endowment to temples of Amun, And those who had this title : "Karomama" granddaughter "Osorkon I" of Twenty-Second Dynasty ( Figure 38), "Shop N Obt" daughter of "Osorkon III" in Twenty-third Dynasty, "Amon Redis" daughter of King "Kashta" of Twenty-fifth "Nubian Dynasty" ( Figure 3), And the daughter of her brother "Shop N Obt II " daughter of King baanky ( Figure 39) . $\left({ }^{37}\right.$ )

\section{The Care and affection}

Ancient Egypt characterized of the feature's living stability and the family desire for interdependence in the life and the other world, As a most important attributes ideals of the family life in ancient Egypt feature, So parents always deliberately to good attention for children and care for them and the bestowal of love for them, Especially girls, Which alludes it through technical archaeological product, Artists always emphasized in the folds of various pictorial landscape, Which express about the love and affection that fathers bestows it to their children, Confirming in writing to register the phrase his beloved son or beloved daughter, And through the literature is also about the relationship between the children and them parents, Which characterized by love.

The most beautiful examples that embody the spirit of mutual affection between parents and their daughters on the Royal level those scenes that portrays the King Akhenaten and his family, Where we see him raising and kissing his daughters, Also accept their play with him in delight (Figure 19.20), And scene of Tall El Amarna for the Queen with her daughter, The scene touch the human heart( Figure 40).

37 - Daumas, la Civilisation de 1,Egypte Pharaoique, p.102; Leclant, MDIAK 15, 1957, pp.166-167. 
At the level of individuals, There are many archaeological evidences given the same meaning, For instance the statue of mother combing her daughter hair, It portrays attention and care with love and affection ( Figure 7 ), And through the scenes portrayed on the walls of tombs notes that the head of the family is keen on having entertainment for the sons and daughters, When he came out for a stroll or enjoy fishing or bird does not account for pleasure alone, But accompanied by his sons and daughters, We see the boy carrying a hunting or practicing it, Either the girl sitting beside his father legs harvested flowers for herself and her parents or to work perfumes of them, Or stuck stems strong papyrus to preserve the balance of the boat while father rushes fishing with his stick or spear ( Figure 23.29), In addition to the meaning of ideological hunting scenes, As well as their participation play, As the scenes play a game of Cent ( Figure 26.27), And the walls of Bany Hassan tombs bearing many scenes of girls games expresses a concern them and portrayed their happiness through the game know swivel girls "Doart El Banat" ( Figure 41).

Through the story of "Sinuhe" we understand that the daughters of king Senusret I ihieddin their father sometimes by poetic hymns and musical signatures even in the presence of close guests.

Among the most important features of incubation care and provide nannies and lactating even with the mother's ability to breast-feeding, and spending on them and their education and processing at marriage with furniture and pay dowry when needed . $\left({ }^{38}\right)$

\section{The Education}

Although the education was for the boys mainly, The girls did not deprive him completely, Through spaced individual documents discern that some of the girls have learned read and

38 - Pestman, Marriage and Matrimonial Property in Ancient Egypt, Brill, 196, pp.162-163; Abd ul Aziz Saleh, Education in ancient Egypt, Cairo, 1966, pp.25-34. 
write, But in their homes, As they have benefited with which learned in their lives, and tasted literature and communicated by it, Even some of their have a writer title, And perhaps they inherited as a profession for fathers, We see some of them write the Queen messages, And of whom are attributed to participate in some of the affairs of the judiciary and some of the affairs of the ministry at the end of the Old Kingdom, And there is possibility establishment documents house " Archives" in Dandara during the Eleventh Dynasty, Fed her contents a great educated lady and nurtured her daughter, And devoted a supervisor for her to organize and protects their ammunition, and some of them was responsible for educating young foreigners on behalf of the Royal palace in Ramesside reign, And of them took the title supervisor of the wise, The doctor "Bshet" was supervisor on Royal palace doctors, There was some manuscripts of Ramesside reign Includes a reciprocal literary messages to females of middle class, Which confirms teach them, One of them visited Memphis for once, And wrote to her friend lived in Thebes, And through letters describing the city and its beauty and the extent promoted life in out, As there were a few small specialized institutes vested in the religious dancing education of girls to work with priesthood in temples and participate in religious festivals, And it has certainly become parents provide education for their daughters ( Figure 42).

One manifestation interest education of Royal daughter providing wise teacher, It was not Queen Hatshepsut interest in educating her daughters less attention of other pharaohs educating their daughters, She has been entrusted teaching her daughter to the Engineer "Snmot" and Commander "Ahmose Bn Nekhbet", Who says in his texts " Amounted to happy aging and I am one of those who live within the confines of the King, "The Holy wife" the big royal wife "Ma $\mathrm{Ka} \mathrm{Ra"} \mathrm{has} \mathrm{bestows}$ blessings because I assumed breeding eldest daughter Princess Neferu Ra since she was a baby", Because he was warrior must 
to designation another teacher, He was "Snmot" and the Princess portrayed with him in many sculptures, That reflect the extent of interest, love and care for her (Figure 43.44, 45). $\left({ }^{39}\right.$ )

\section{The Securing the Future}

As far as interest the ancient Egyptian for his daughters ,their care, their protection and there rejoices during his life, Eagerness on secure their futures after his death, despite the absence of legislative laws explicitly for divide the inheritance in Egyptian early ages, But custom solution instead of law, So he was recommended as it deems beneficial to his children without depriving the girl, But in Late Period there is documents show that the daughter's share of legacy equal to one-third with the right of the eldest daughter inheritance if her sisters died without a successor .

Was also keen to secure her safe shelter came on Ostracon of the New Kingdom that father gave his daughter a share to live in his home, He gave it to her to protect if she divorced. $\left({ }^{40}\right)$

According to a story "Betty East," of late Period the father gave his daughter a house as a gift on the occasion of her marriage, The father always when division his property on his children give the girls a house or share in the house to guarantee them shelter especially who did not marry or her husband died or divorced. $\left({ }^{41}\right)$

\section{The work}

Ancient Egyptian society agreed on women work appropriate to the areas of private and public life of civil and religious affairs, as befitted its values and principles, traditions and beliefs, If she enjoyed a efficient personal, As well as the main role in the care

39 - F. Tiradritti, The Treasures of the Egyptian Museum , pp.166- 168- 189; Pierre Montet, La vie Quotidienne en Egypte "Au temps des Ramses XIII-XII, Tr. Aziz Morcos, Le Cair, 1997, pp.75=76. Said Ismail, Education in the ancient Egyptian civilization, Cairo, 1996, p. 150 .

40 - F.Petrie, Ostracon, 61; T. Handousa , Marriage and divorce in ancient Egypt, p.93.

41 - F.Griffith,Catalogue of the Domotic Ppyri in the John Rylands library at Manchester, 1909, vol.3, Pap.IX, 9 , - id, Hieratic Papyri from Kahun and Gurob (principally of the Middle Kingdom), London, 1898, I,1 
of her home and her husband and raising their young, Since the character and functions were mostly inherited equal in that character which were taken by both men and women, Many girls have worked with their mothers in the same profession or as assistant of them in various archaeological evidence, That is certainly in the working of the general class.

Among the most important of those crafts practiced by girls and scenes described her archaeological scenes portrayed on the walls of the individuals tombs including:

Farming as uprooting weeds, Sowing grain, Collect grain ,Pick up what flaking them while harvest, And provided the birds of the vineyards by small sticks and slingshots, Both in the small father,s land or Peer wage in other,s land, There is a scene of the New Kingdom for two girls fighting during collecting wheat spikes of Menna,s tomb in Sheikh Abdul Qurna of Thebes (Figure 46) . $\left({ }^{42}\right)$

The work as a maid, But to work as a free maid there are many condition and number of Rules, In the forefront the work must be appropriate for her age and not be tired for her or overloaded as understood of a discourse Papyrus in Louvre Museum under No. b 3230 of the New Kingdom $\left({ }^{43}\right)$, Including scene of maid her features suggest possibility of being a Nubian, She holding a baby wrapped in the cloth around her chest in one of the processions rites funeral of knn,s tomb of Deir El Madina (Figure 47$)\left({ }^{44}\right)$, There are many scenes for little girls service to guests at the concerts, But sometimes those girls are daughters of the present women at the party, Not as a practitioners servers, There is many scenes of New Kingdom from Thebes portrays this meaning, Including a good scene painted on plaster of "Neb

42 - Z.Hawass, Le Tombeau de Menna, Le Caire, 2002, p.23,pl.XXXVA; W, Wreszinski, Atlas, vol.I, Genéve- Paris, 1988, Taf.233.

43 - S.R.K. Glanville, "The letters of AaHmōse of Peniati", JEA 14, 1928, p.309; T. E. Peet, "Two eighteenth Dynasty letters papyrus Louvre 3230", JEA 12, 1926, 70-74, pl . .XVII.

44 - M.B.Bruyére, Tombes Thébaines de Deir el Médineh "MIFAO 1952 Tome LXXXVI", p.180, fig. 121 . 
Amon" tomb of New Kingdom in British Museum, Portrays a girl put an earring in her ears, a bracelets and lay hold of flowers on her chest, Offers wine for guests ( Figure 48) $\left({ }^{45}\right)$, Another scene for two girls one of them pass the dining on guests of Rekh - Mi - Ra,s tomb of Thebes ( Figure 49) $\left({ }^{46}\right)$, And scene of a girl offers a range of perfumes for women of Geser $\mathrm{Ka} \mathrm{Ra}$ Sneb of Thebes ( Figure 50) $\left({ }^{47}\right.$ )

There are some girls who worked in the textile field, as were some girls company mourners during the funeral either to carry the child as stated scene of Kha M Hat tomb preserved at the Berlin Museum, Where portrayed a young girls naked and carrying babies in a piece of cloth around the chest and hold up their hands like mourners ( Figure 51 ) $\left(^{48}\right)$, Or to do the same movements such as mourner major as stated scene of the Minister Ra Moza tomb of Thebes ( Figure 31).

\section{Results of the study}

Through the presentation of these archaeological scenes, which are only examples, The Egyptian civilization rich diverse archaeological evidence, Which may numbering hundreds and perhaps even thousands conclude the following :

1- The Ancient Egyptian family characterized by stability and cohesion family.

2- The Ancient Egyptian attention to portray all children, Boys and girls in the same size and the same situation in sculpture, And interest in respect of the daughter portrayed

45 - R. Parkinson, The Painted tomb-Chapel of Nebamun, 2008, pp. 74 f,81,87; Z.Hawass, Silent Images Women of pharaonic Egypt, Cairo, 1995, p.112.

46 - Davies, N.de G., The Tomb of Rekh - Mi -RE at Thebes, vol. II, New York, 1973, pl.LXVI; Vogelslsang- East wood, G.,Pharaonic Egyptian Clothing, New York, 1993, pp.96 f, fig.8-13; Dodson, A. \& Ikram, S., The Tomb in Ancient Egypt, London, 2008, fig, 253.

47 - Davies, Nina de Garis, Scenes from some Theban Tombs, Oxford, 1963, pl.VI.

48 - J.Malek \& E.Miles, JEA 75,p.227, fig 1; E.Lüddeckens, " untersuchungen über religiösen gehalt, sprache und form der Ägyptischen Totenklagen" MDAIK 11, 1943, Taf.15. 
entertainment topics and care, While portrayed of boys in serious topics such as the various crafts in the inscription.

3- Reasonable convergence in the treatment of fathers to sons its equal in the boys with the girls.

4- Justice relative to bequeathing sons of two gender ratios close though outweigh sons over daughters somewhat in late period.

5- Justice relative to accept the community to draw the appropriate female activities.

6- Weak position with respect to the daughter of the other world Gqaúd although the birth of all children were well received, the cravings for sons were common to all people, High priest Ptah said in "Al Amier Al Mood" Prince promised story a phrase "once happened that the king did not beget a son male, he was very sad, So he Prayed to the gods besought son, So they decided to give him a male", The role of son is protect his father's name and his duty as stipulated in the texts of religious books related to the other world, And demonstrated by the hundreds of inscriptions to take over burial, And maintenance of his tomb.

The general, the daughter of a continued ancient Egyptian women have enjoyed great prestige make it superior to peers of women in other contemporary civilizations, and in that says Max Miller, "There is no ancient or new people may raise the status of women as much as lifting the inhabitants of the Nile Valley ". 


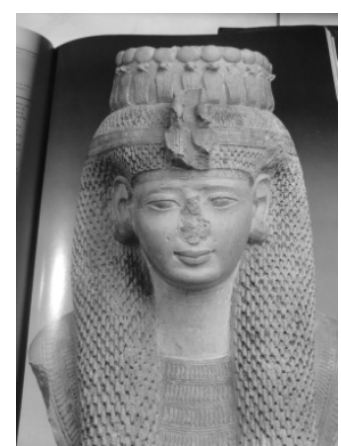

Fig: 1

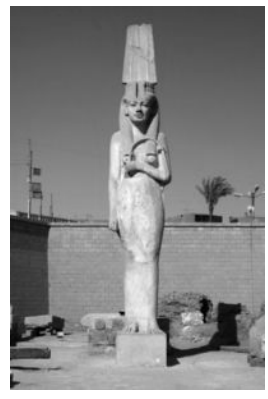

Fig:2

F. Tiradritti, The Treasures of the Egyptian Museum

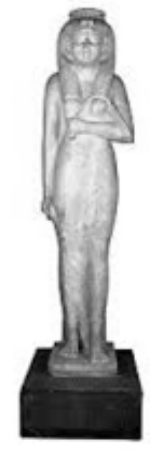

Fig : 3

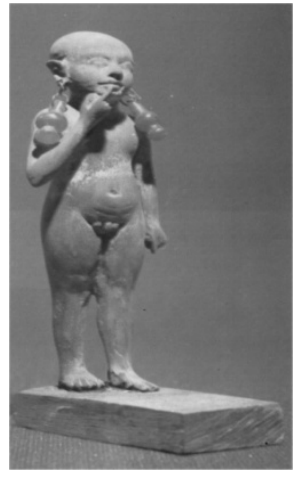

Fig :4

F. Tiradritti, The Treasures of the Egyptian Museum

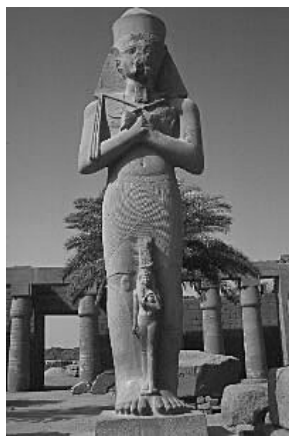

Fig :5

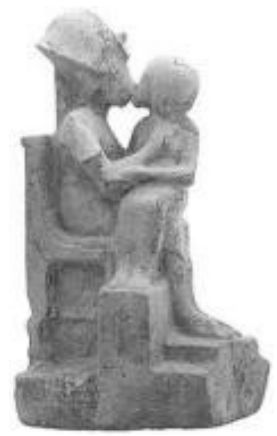

Fig :6

F. Tiradritti, The Treasures of the Egyptian Museum 
دراسات في آثار الوطن العربي 16

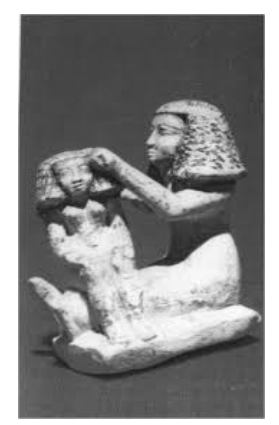

Fig: 7

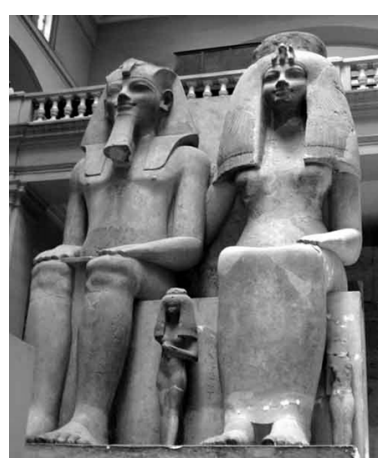

Fig:8
T.Handousa , Marriage and divorce in ancient Egypt

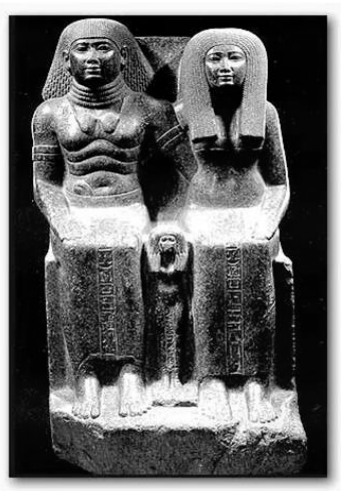

Fig:9

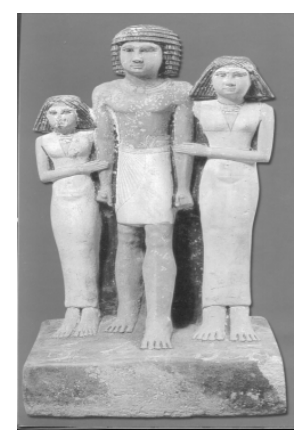

Fig:10

F. Tiradritti, The Treasures of the Egyptian Museum

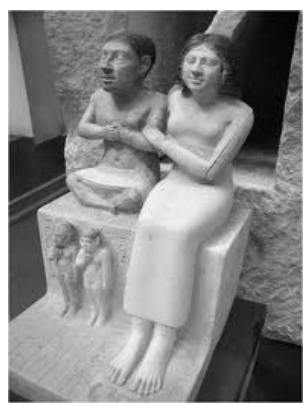

Fig:11

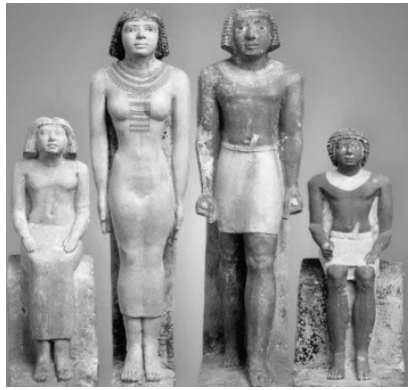

Fig:12

Catalogue of the Egyptian Museum 
دراسات في آثار الوطن العربي 16

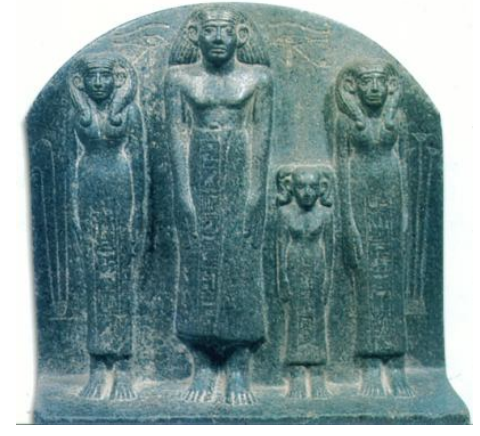

Fig : 13

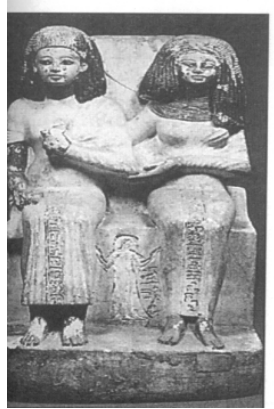

Fig : 14
Catalogue of the Egyptian Museum

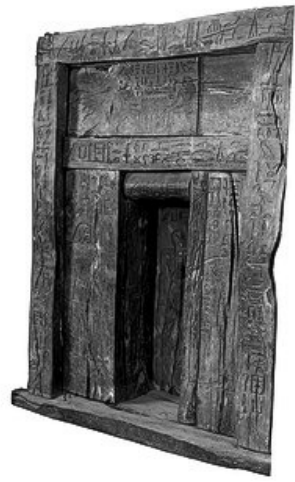

Fig : 15
T.Handousa , Marriage and divorce in ancient Egypt

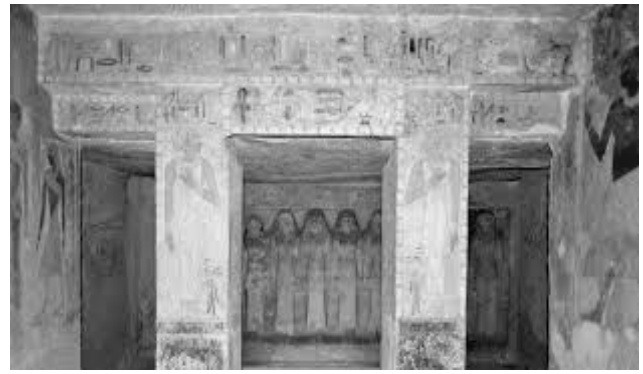

Fig : 16

M.Ismail, Funerary architecture in PharaonicEgypt Catalogue of the Egyptian Museum
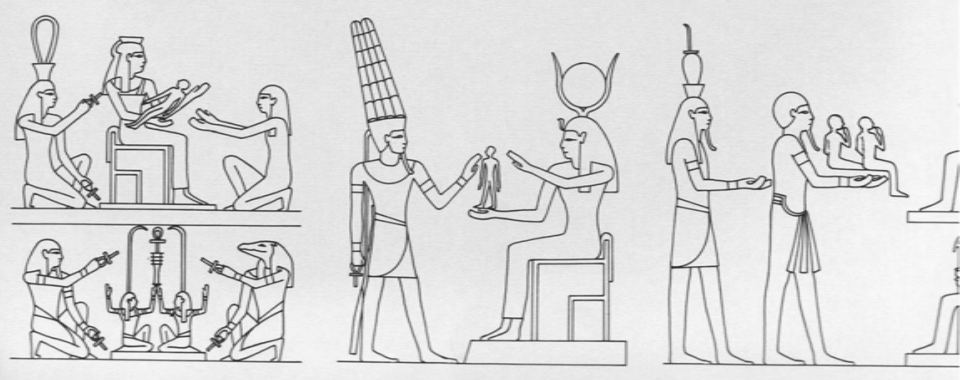

Fig : 17

A. Halim Nureddin, the history and civilization of ancient Egypt 


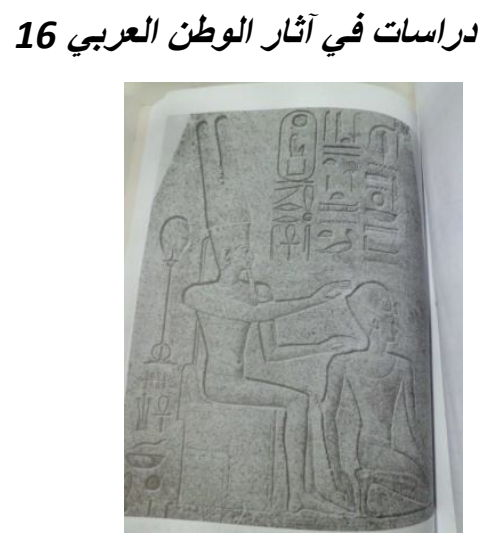

Fig : 18

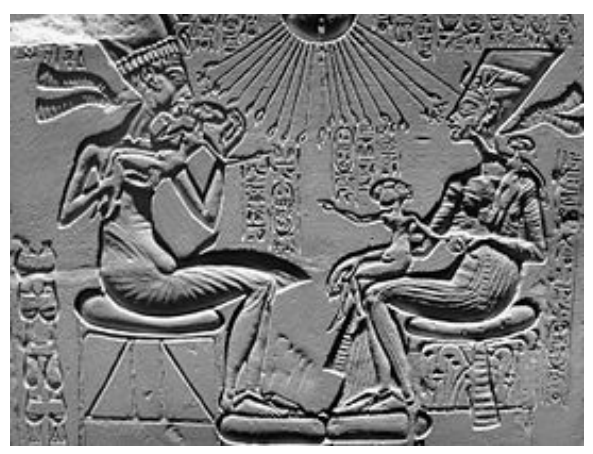

Fig : 19

Pascal Vernos, Encyclopedia of the Pharaohs

F. Tiradritti, The Treasures of the

Egyptian Museum

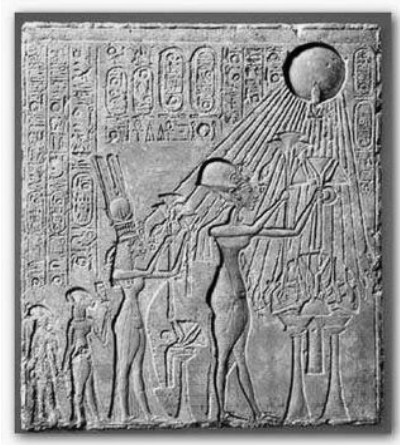

Fig : 20 Catalogue of the Egyptian Museum

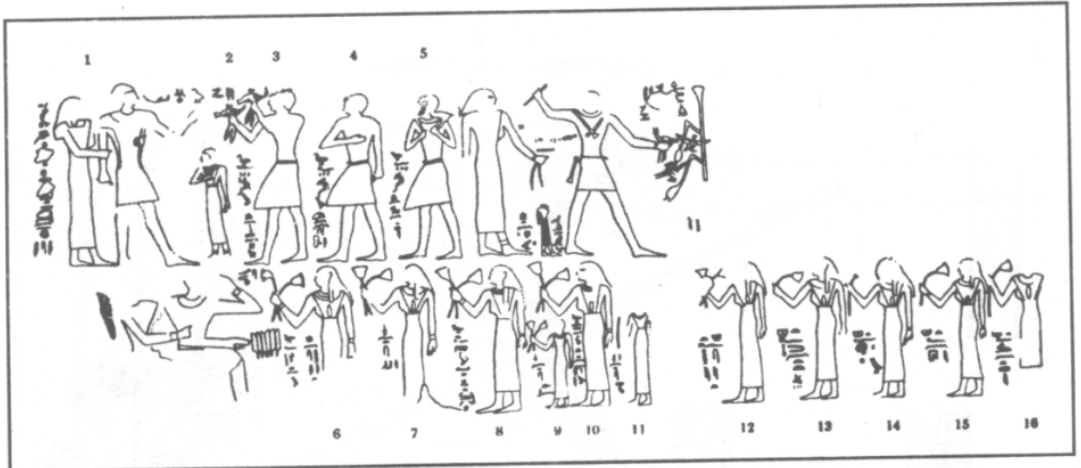

Fig : 21

T.Handousa , Marriage and divorce in ancient Egypt 
دراسات في آثار الوطن العربي 16

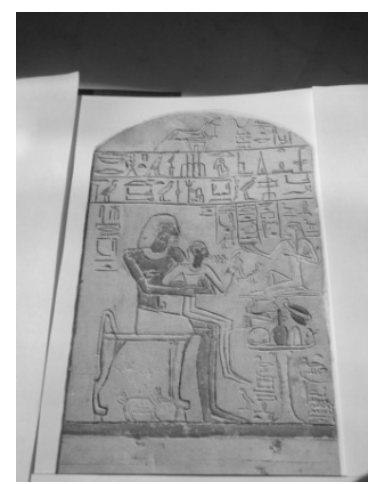

Fig : 22

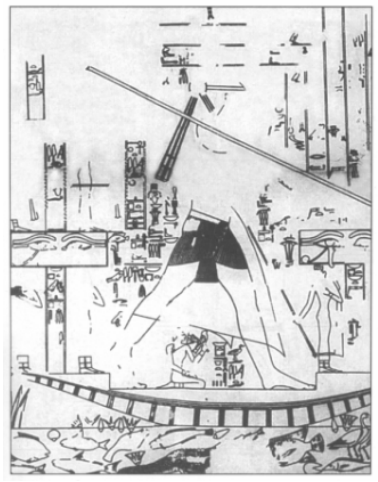

Fig : 23

T.Handousa , Marriage and divorce F. Tiradritti, The Treasures of the Egyptian Museum

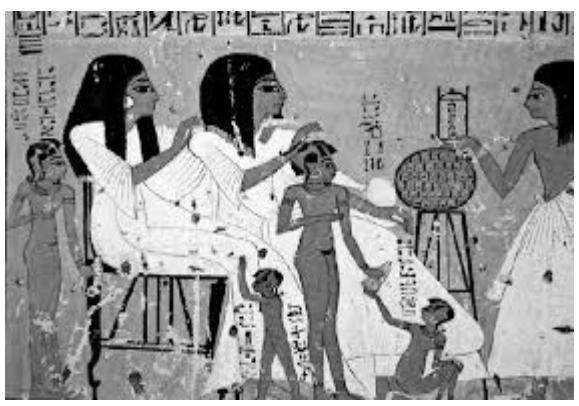

Fig : 24

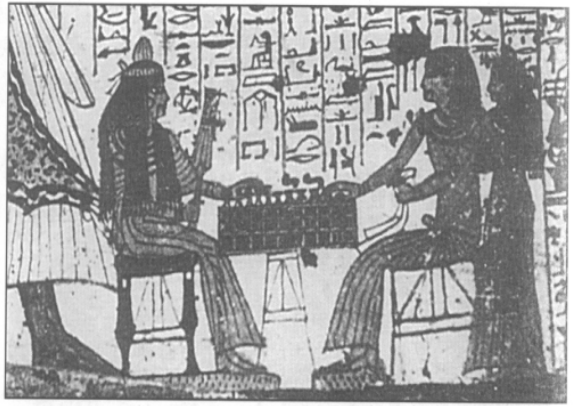

Fig : 25

T.Handousa , Marriage and divorce in ancient Egypt

W. Decket, Sports and Games

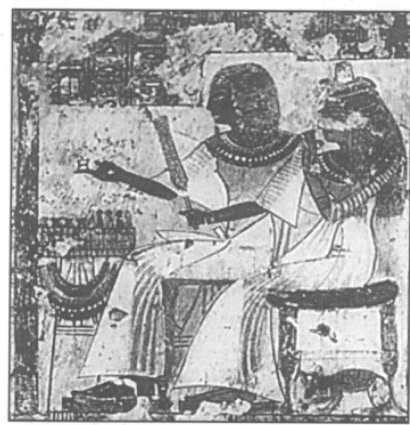

Fig : 26

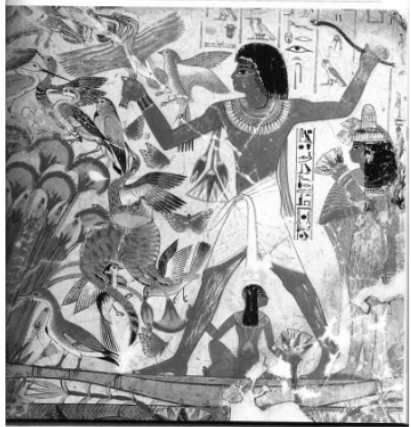

Fig : 27
T.Handousa , Marriage and divorce in ancient Egypt
A.Nur al-Din, The role of women in ancient Egyptian society 


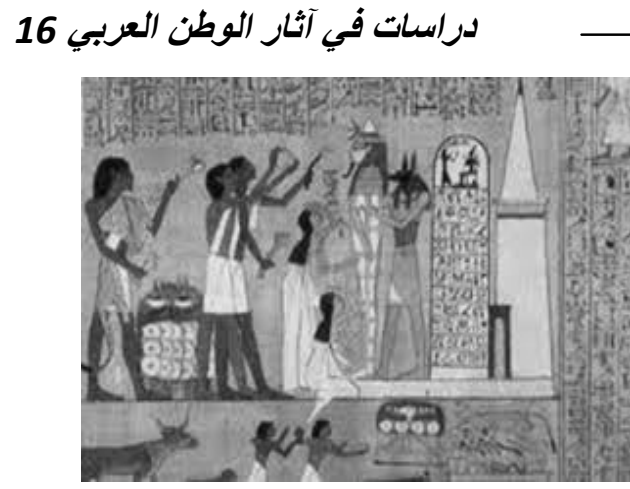

Fig : 28

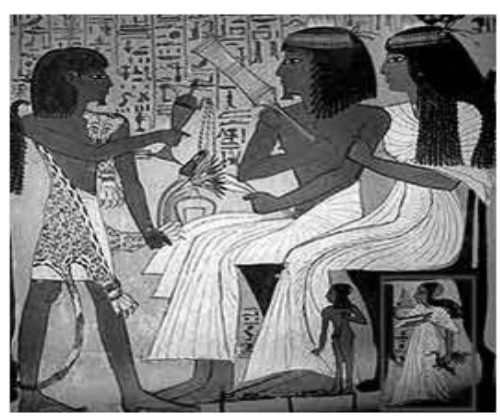

Fig : 29

A.Nur al-Din, The role of women in ancient Egyptian society

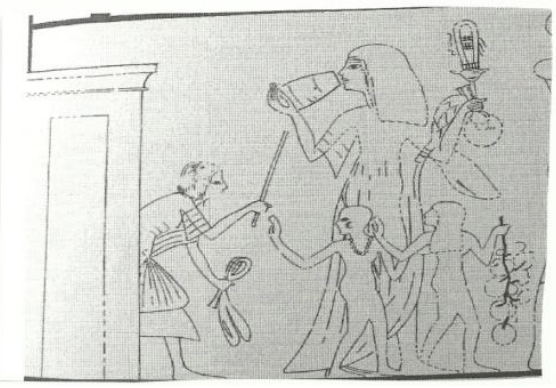

Fig 30

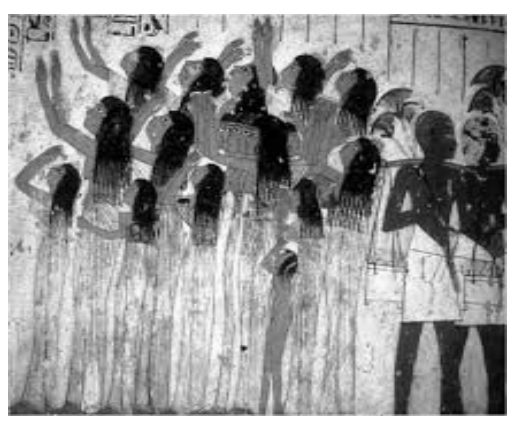

Fig : 31

Christian Dirosh Noblchor, Pharaonic women

N.de G.Davies, The Tomb of Nefer- Hotep

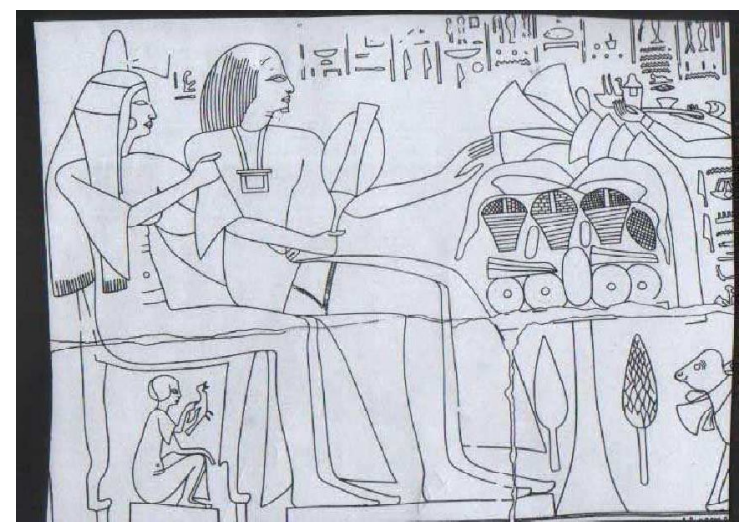

Fig : 32

G.T. Martin, Paser ana Raaia 
دراسات في آثار الوطن العربي 16

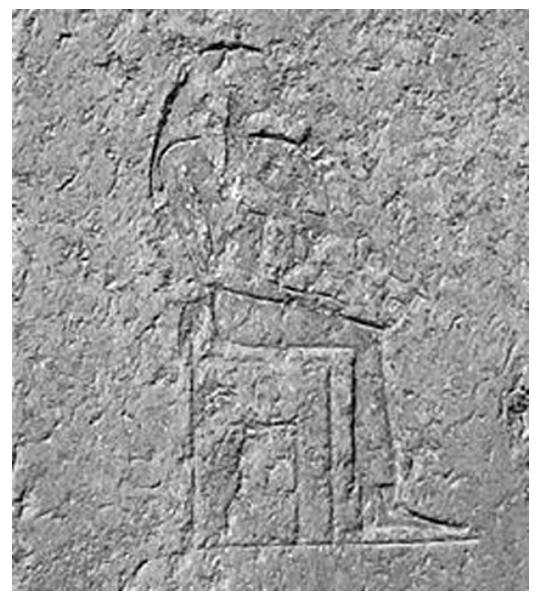

Fig : 33

A.Nur al-Din, The history and Civilization of ancient Egypt

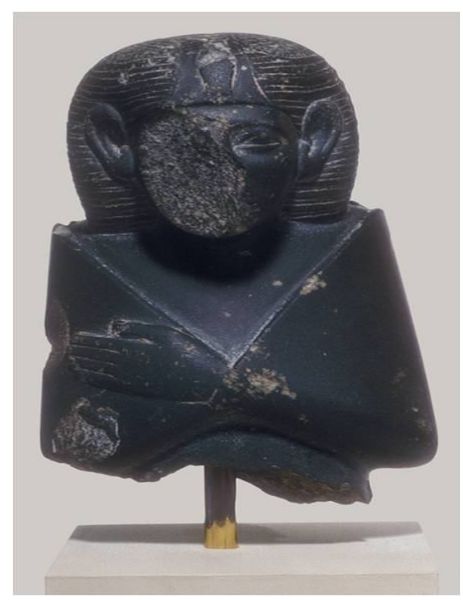

Fig : 35

Weigall, Histoire de I,Egypte Ancienne

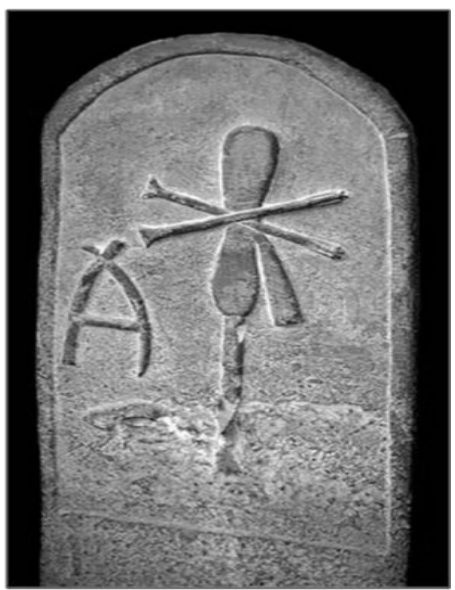

Fig : 34

The Role of women in ancient

Egyptian society

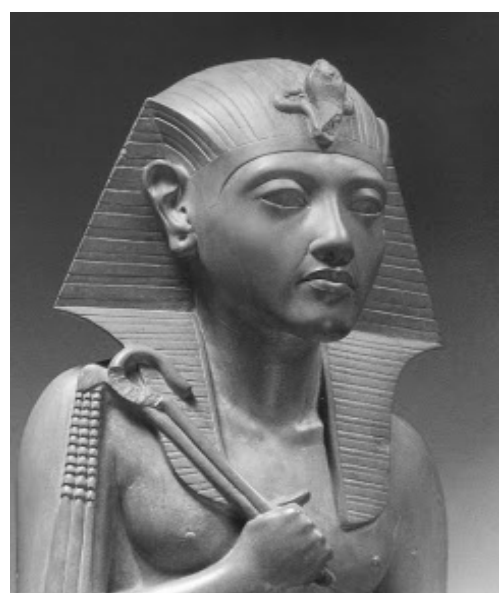

Fig : 36

W.Petrie, Kahun, Gurob and Hawara 
دراسات في آثار الوطن العربي 16

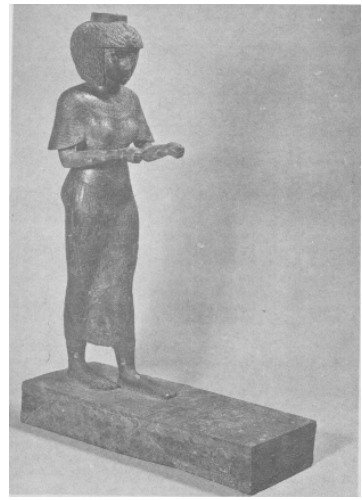

Fig : 37

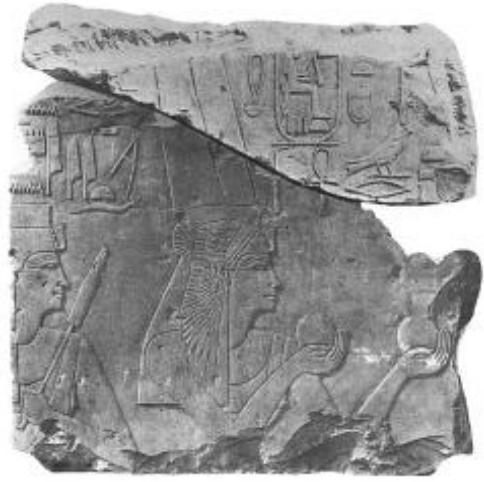

Fig : 38

Nicholas Grimal, The history of ancient Egypt

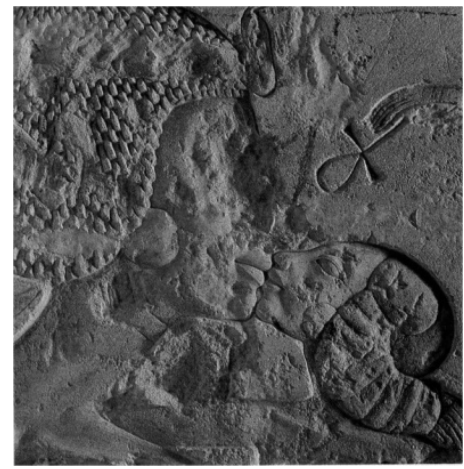

Fig : 39

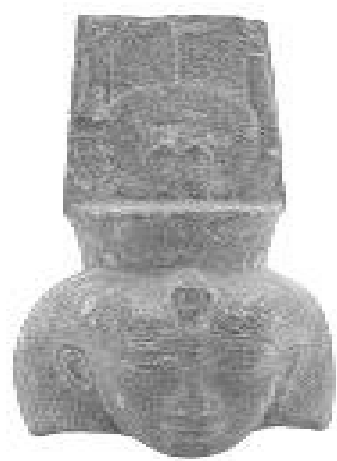

Fig : 40

Daumas, la Civilisation de I,Egypte Pharaoique

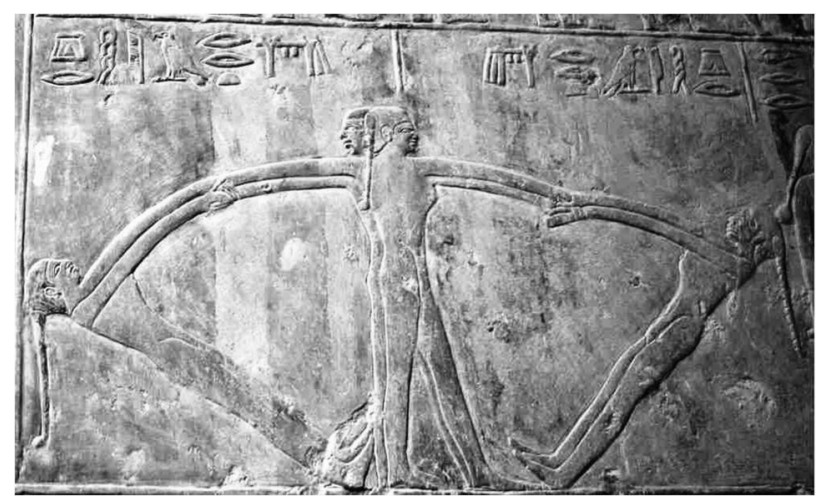

Fig : 41 A.Nur al-Din, Archaeology and Civilization of Egypt 
دراسات في آثار الوطن العربي 16

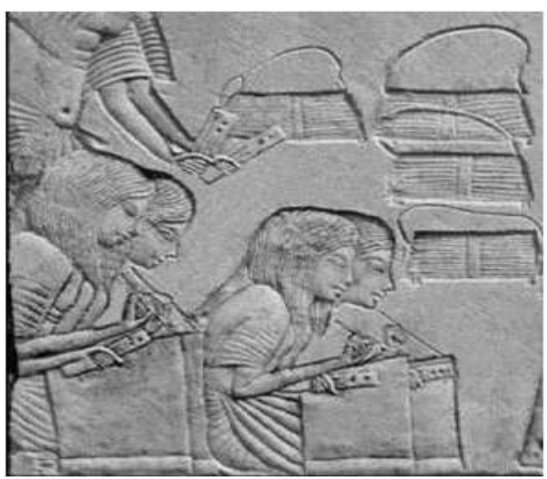

Fig : 42

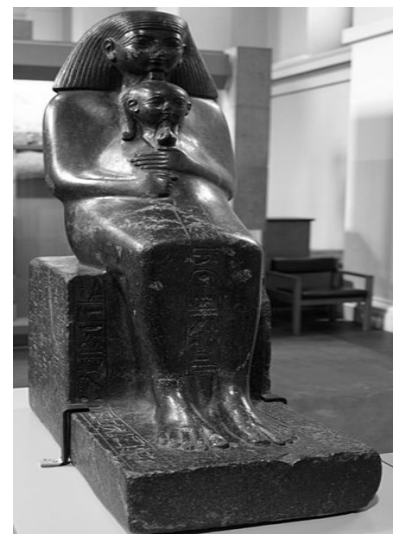

Fig : 44

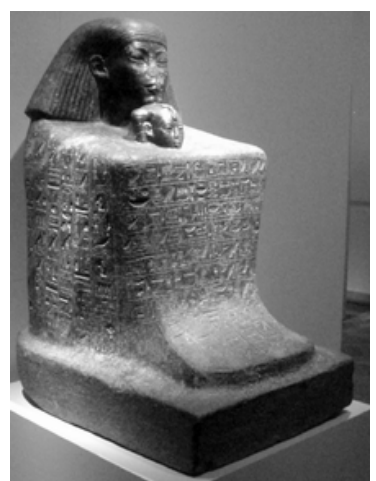

Fig : 43

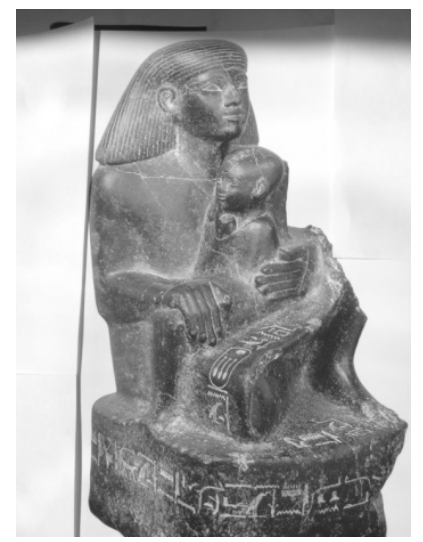

Fig : 45

F. Tiradritti, The Treasures of the Egyptian Museum

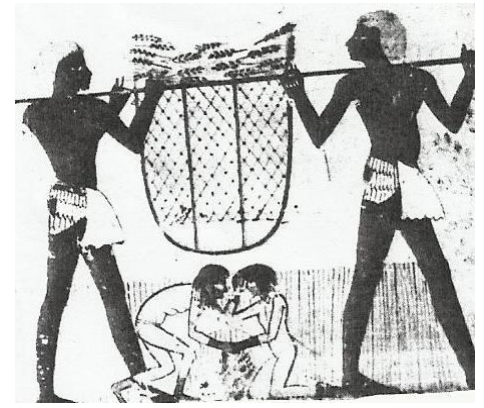

Fig : 46

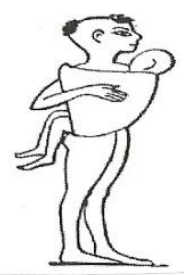

Fig : 47
Z.Hawass, Le Tombeau de Menna
M. B. Bruyére, Tombes Thébaines de Deir el

$$
\text { Médineh }
$$


دراسات في آثار الوطن العربي 16

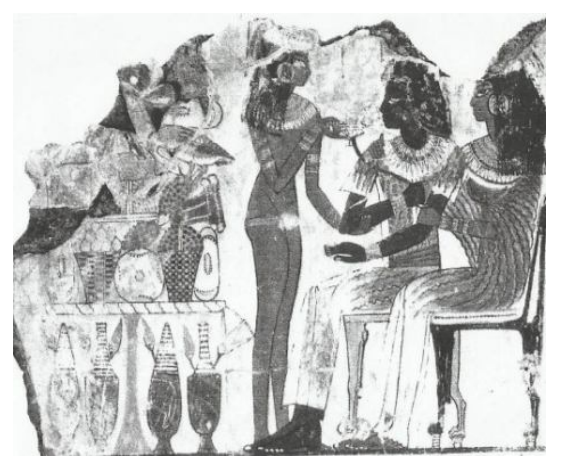

Fig : 48

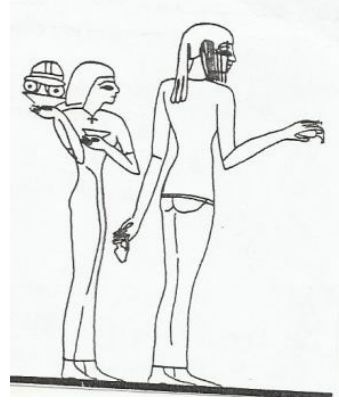

Fig : 49

R.Parkinson, The Painted tomb-Chapel of Neb amun Davies, N.de G.,The Tomb of Rekh$\mathrm{Mi}-\mathrm{RE}$

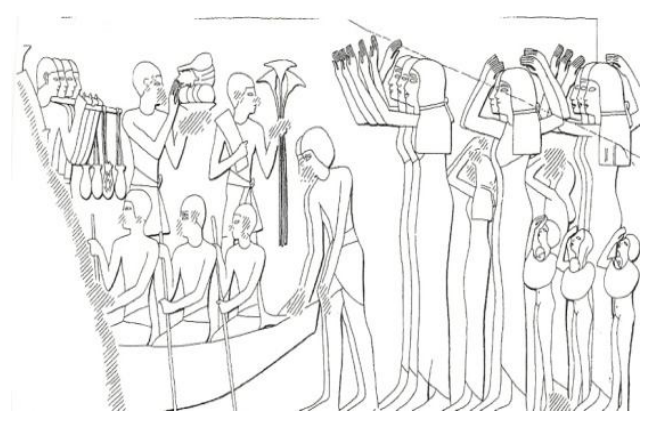

Fig : 50

Davies, Nina de Garis, Scenes of some Theban Tombs

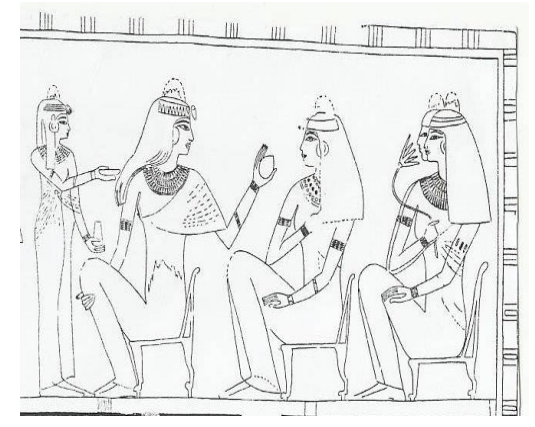

Fig : 51 E.Lüddeckens, " Untersuchungen über religiösen gehalt, sprache und form der Ägyptischen Totenklagen" 